\title{
IDENTITAS GENDER DAN SENSUALITAS TUBUH TANDHAK DALAM PANGGUNG PERTUNJUKAN LUDRUK LEROK ANYAR
}

\author{
Insroatun Naima \\ Institut Seni Indonesia Surakarta
}

\begin{abstract}
Abstrak: Penelitian ini menganalisis ketubuhan para tandhak ludruk pada kelompok Ludruk Lerok Anyar Kabupaten Malang. Penelitian ini penting dilakukan untuk melihat bagaimana tubuh digunakan menjadi alat untuk menunjukkan identitas gender dan bagaimana tubuh digunakan menjadi alat untuk merepresentasikan nilai sensualitas. Identitas gender dan sensualitas tubuh dianalisis menggunakan teori identitas gender dan sensualitas. Penelitian ini menggunakan metode kualitatif, dengan teknik pengumpulan data melalui studi pustaka, wawancara, observasi dan pengamatan video rekaman pertunjukan. Hasil penelitian menunjukkan bahwa panggung ludruk mampu memberikan ruang bagi para transgender sebagai tandhak ludruk untuk menunjukkan identitas keperempuanan. Tubuh para tandhak dikonstruksi melalui serangkaian gerak, gesture, make up dan kostum.
\end{abstract}

Kata kunci: tandhak ludruk, identitas gender, sensualitas tubuh, kelompok Ludruk Lerok Anyar.

\begin{abstract}
This research analyzes "Gender Identity and Tandhak Body Sensuality in Ludruk Lerok Anyar Stage Performance". This research is important to do as it aims to see how body is used as a medium for showing gender identity and how the body is used as a media representing sensuality value. The body's gender identity and sensuality is analyzed through the gender and sensuality theory. This research uses qualitative method, with data gathering technique done by library research, interview, observation, and performance video recording monitoring. The results show that Ludruk performance is capable to give transgenders a space as tandhak ludruk to show their feminine identity. The body of these tandhak are constructed by a set of movements, gestures, make-up, and costumes.
\end{abstract}

Key word: tandhak ludruk, gender identity, body sensuality, Ludruk Lerok Anyar community

\section{Pendahuluan}

Teater tradisional merupakan bentuk teater yang dihasilkan oleh kreativitas masyarakat dari suatu suku atau etnis tertentu di Indonesia. Teater tradisional bertolak dari sastra lisan yang berakar dari budaya dan tradisi masyarakat pendukungnya (Achmad, 2006). Mulanya teater tradisional merupakan bagian dari upacara keagamaan dan upacara adat yang ada sejak zaman pra-Hindu, kemudian berkembang menjadi seni hiburan.

Ciri utama teater tradisional yaitu selalu menggunakan aspek tembang, tari, karawitan, akting dan dagelan. Kelima unsur tersebut hampir selalu dapat dijumpai di berbagai pertunjukan teater tradisional. Selain itu, fungsi lain dari teater tradisional adalah tersedianya ruang yang memungkinkan para pemainnya untuk 
menunjukkan identitas gendernya, seperti halnya dalam pertunjukan ludruk.

Ludruk merupakan salah satu kesenian rakyat berasal dari Jawa Timur. Dalam pertunjukan ludruk semua pemainnya adalah laki-laki. Peran perempuan pun dimainkan oleh laki-laki yang disebut Tandhak ludruk. Tandhak merupakan istilah untuk memanggil tokoh perempuan yang diperankah oleh laki-laki dalam sebuah pementasan ludruk. Kemunculan karakter perempuan yang dimainkan oleh laki-laki ini sebenarnya tidak hanya muncul pada pertunjukan ludruk, namun juga muncul pada beberapa jenis kesenian tradisional lainnya. Misalnya dalam pertunjukan Lengger Lanang, lengger yang seorang perempuan itu ditarikan oleh seorang lakilaki. Seorang laki-laki yang berprilaku layaknya perempuan dalam pandangan psikologi disebut dengan istilah transgender.

Transgender adalah istilah yang digunakan untuk mendeskripsikan orang yang melakukan, merasa, berfikir atau terlihat berbeda dari jenis kelamin yang ditetapkan saat mereka lahir. Transgender tidak menunjukkan bentuk spesifik apapun dari orientasi seksual orangnya. Orangorang transgender dapat saja mengidentifikasi dirinya sebagai heteroseksual, homoseksual, biseksual, panseksual, poliseksual, atau aseksual (Yash, 2003).

Definisi yang tepat untuk transgender tetap mengalir, namun mencakup: tentang, berkaitan dengan, atau menetapkan seseorang yang identitasnya tidak sesuai dengan pengertian yang konvensional tentang gender laki - laki atau perempuan, melainkan menggabungkan atau bergerak di antara keduanya. Orang yang ditetapkan gendernya, biasanya pada saat kelahirannya dan didasarkan pada kelaminnya, tetapi yang merasa bahwa deskripsi ini salah atau tidak sempurna bagi dirinya (Yash, 2003).
Pada hakikatnya, masalah kebingungan jenis kelamin atau yang lazim disebut juga sebagai gejala transseksualisme ataupun transgender, merupakan suatu gejala ketidakpuasan seseorang karena merasa tidak adanya kecocokan antara bentuk fisik dan kelamin dengan kejiwaan, ataupun adanya ketidakpuasan dengan alat kelamin yang dimilikinya. Ketidakpuasaan tersebut direpresentasikan dalam bentuk dandanan, make up, gaya dan tingkah laku, bahkan sampai kepada operasi penggantian kelamin.

Salah satu akibat transgender munculah istilah waria yaitu wanita pria. Waria adalah seorang pria yang secara psikis merasa adanya ketidakcocokan antara jati diri yang dimiliki dengan alat kelaminnya, sehingga akhirnya memilih dan berusaha untuk memiliki sifat dan prilaku lawan jenisnya yaitu wanita. Fisik mereka laki-laki namun cara berjalan, berbicara dan dandanan mereka mirip perempuan. Pada umumnya seseorang yang berbeda atau tidak normal dianggap berbeda dan tidak bisa masuk dalam kelompok yang sama, karena mereka dianggap memiliki perbedaan yang membuat orang memandangnya tidak layak untuk hidup berdampingan. Mereka dikucilkan dari lingkungan, dijadikan bahan pembicaraan atau dicemooh oleh masyarakat sekitar dan dianggap dapat membawa pengaruh negatif untuk lingkungan masyarakat.

Masyarakat memandang seorang waria dengan pandangan negatif. Mereka menganggap bahwa seorang waria telah mengubah kodrat yang diberikan Tuhan sejak lahir dan itu merupakan larangan agama. Waria dianggap sebagai penyakit dan sampah masyarakat, akibatnya mereka pun tidak mendapatkan hak sebagai sesama warga negara.

Panggung ludruk memberikan ruang bagi para waria untuk dapat menunjukkan dirinya yang sejati tanpa harus ditutup-tutupi 
dan diskriminasi. Ludruk mengangkat waria dari yang awalnya dianggap sebagai sampah masyarakat menjadi bintang di panggung yang dinanti-nantikan kehadirannya. Fenomena tersebut terjadi pula pada kelompok Ludruk Lerok Anyar di Kabupaten Malang yang menyediakan ruang untuk tandhak (transgender) dalam menunjukkan identitasnya. Tandhak Ludruk Lerok Anyar mengkonstruksi tubuh lakilakinya menjadi tubuh perempuan cantik di atas panggung.

Tandhak dalam ludruk menjadi sesuatu yang istimewa serta menarik perhatian penonton laki-laki. Tubuh para tandhak menggambarkan sensualitas dengan menonjolkan bagian-bagian tertentu dari tubuh perempuan yaitu: lekuk tubuh, dada yang indah, kaki yang panjang, rambut bersanggul, payudara yang besar, bibir yang sexy, pantat yang bergoyang-goyang, suaranya yang halus serta polesan make up yang menor, memberikan kesan tubuh yang sensual. Hal itu dipertegas melalui kidungan yang dinyanyikan dengan gaya suara seperti perempuan dan kata-kata yang sengaja diucapkan untuk merangsang hasrat kaum laki-laki.

Dalam pertunjukan ludruk, tubuh tandhak menunjukkan identitas gender sekaligus merepresentasikan nilai sensualitas. Identitas gender adalah suatu identitas yang menunjukkan apakah seseorang itu bergender laki-laki atau perempuan. Seorang laki-laki yang berada dalam tubuh perempuan (sifat-sifatnya) dan perempuan yang berada dalam tubuh lakilaki. Menurut Butler, tidak sekedar menirukan feminitas perempuan. Lebih jauh, mereka juga menunjukkan bahwa femininitas adalah sebuah praktik peniruan, baik itu ketika dilakukan waria maupun perempuan. Singkatnya, penentu the effect of realness adalah kemampuan untuk menghasilkan naturalised effect (Butler, 1993). Tidak ada gender yang benar-benar nyata, yang ada hanyalah proses imitatif yang dilakukan secara terus-menerus sehingga membentuk efek yang nyata. Selain itu tubuh para tandhak juga merepresentasikan suatu nilai sensualitas. Sensualitas merupakan bentuk kesenangan yang dirasakan oleh indera yang disebabkan oleh sensasi tubuh, sehingga menimbulkan khayalan-khayalan penonton saat menyaksikan tubuh tandhak.

Peneliti tertarik melakukan penelitian untuk mengetahui bagaimana tubuh menjadi alat menunjukkan identitas gender dan bagaimana tubuh merepresentasikan nilai sensualitas, dengan menonjolkan penggambaran tubuh perempuan sehingga dapat memunculkan fantasi tertentu untuk menarik minat penonton. Penelitian ini hendak melihat bagaimana tubuh direkonstruksi menjadi alat untuk membentuk identitas dan merepresentasikan nilai sensualitas melalui peran para tandhak.

Kajian ini akan mengupas mengenai identitas gender dan sensualitas tubuh tandhak dalam panggung pertunjukan Ludruk Lerok Anyar. Kemudian, kajian ini akan menggunakan teori Judith Butler mengenai identitas gender dan sensualitas untuk mempertajam analisa. Lebih detail penelitian ini akan menjawab permasalahan mengenai: (1) bagaimana tubuh menjadi alat untuk menunjukkan identitas gender; dan (2) bagaimana tubuh merepresentasikan nilai sensualitas.

\section{Tinjauan Pustaka}

Identitas gender adalah suatu identitas yang menunjukkan apakah seseorang itu bergender laki-laki atau perempuan. Seorang laki-laki yang berada dalam tubuh perempuan (sifat-sifatnya) dan perempuan yang berada dalam tubuh laki-laki. Identitas gender merupakan efek yang diproduksi oleh individu karena menampilkan praktikpraktik, Butler menyebutnya sebagai gender act, yang secara sosial disepakati sebagai 
penanda identitas sebagai perempuan atau laki-laki. Menurut Butler, tidak sekedar menirukan feminitas perempuan. Lebih jauh, mereka juga menunjukkan bahwa femininitas adalah sebuah praktik peniruan, baik itu ketika dilakukan waria maupun perempuan. Singkatnya, penentu the effect of realness adalah kemampuan untuk menghasilkan naturalised effect (Butler, 1993).

Butler (1990) menggambarkan bagaimana realness atau kebenaran tentang gender dan seksualitas diproduksi dan direproduksi melalui serangkaian gerak, gesture, dan hasrat yang mengimplementasikan identitas gender paling essensial. Waria, obyek yang dikaji Butler , harus melakukan serangkaian praktik dan procedural tertentu untuk memperoleh bentuk yang diidealkan, gesture dan penampilan mereka dianggap feminin.

Waria bukan sedang meniru yang asli, melainkan menginspirasi bahwa yang asli itu tidak ada, yang ada hanyalah pertunjukan yang terus menerus diulang hingga membentuk efek yang benar-benar alamiah. Praktik yang demikian juga sekaligus memparodikan anggapan-anggapan tradisional mengenai apa yang disebut feminitas dan maskulinitas. Bahwa penis tidak harus berperan maskulin, dan vagina juga tidak harus feminin.

"... the notion of an original or primary gender identity is... parodied within the cultural practices of drag, cross-dressing, and the sexual stylization of butch/fame identities ..."'(Butler, 1990).

Ekspresi gender tidak ada di balik identitas gender, karena gender adalah sebuah proses imitasi, pengulangan dan performativitas yang tidak pernah berhenti. Identitas gender, karenanya, bukanlah sebuah hal yang tetap.

Tubuh merupakan keseluruhan struktur fisik organisme manusia, yang terdiri atas bentuk tubuh yang kasat mata dan tidak kasat mata. Dalam tubuh manusia terdapat serangkaian antara jiwa dan raga, bukan hanya tangan, hidung, kepala, kaki, mata, rambut, rahim, vagina, penis, jantung, dan lain-lain tetapi mencakup seisi jiwa baik itu pikiran, perasaan, hati dan atas apa yang tak terlihat oleh mata namun bisa dirasakan dalam satu naluri manusia. Semua itu ada dalam satu rangkaian yang terbentuk menjadi satu yaitu tubuh.

Hasrat diasosiasikan sebagai harapan atau keinginan yang bersifat tidak disadari. Freud (2006) melihat hasrat berhubungan dengan "kepenuhan" dan tersimpan dalam wilayah tidak sadar, serta menjadi daya pendorong bagi tindakan seseorang dalam mencari pemenuhan atas hasratnya yang dipahami sebagai hasrat seksual. Pengertian "hasrat" dalam filsafat Hegel berbeda dari apa yang dipahami oleh Freud. Hegel memahami "hasrat" sebagai "hasrat akan pengakuan'. Hal ini dijelaskan dengan dialektika tuan-budak. Seseorang berjuang untuk mendapatkan pengakuan dari sesamanya karena dengan cara demikianlah orang tersebut mendapatkan kepastian dirinya. Proses pengakuan ini terjadi secara seimbang dan bersifat timbal balik, di mana pengakuan diberikan seseorang, sepadan dengan orang yang diakui. Hegel beranggapan bahwa kepastian diri terbentuk dari proses dialektika antara hasrat dengan pemenuhannya. Kepastian diri inilah yang diperjuangkan oleh manusia karena dengan memiliki kepastian diri, manusia seakan menemukan posisinya dalam dunia, dan membawa manusia kepada kebebasan. Freud (2006) juga mengatakan bahwa subjek mencari kepastiannya, ia memahami bahwa proses dialektika "hasrat" adalah 'hasrat akan pengakuan' dan penekanan "hasrat" pada manusia adalah 'perjuangan akan pengakuan' tersebut. 


\section{Metode}

Penelitian ini menggunakan metode kualitatif, dengan teknik pengumpulan data melalui studi pustaka, wawancara, observasi dan pengamatan video rekaman pertunjukan. Penulis melakukan studi pustaka untuk mencari data yang diperlukan dan teori yang relevan untuk kajian Ludruk Lerok Anyar, yang kemudian dilanjutkan dengan wawancara dengan pelaku seni. Penulis juga melakukan observasi terhadap berbagai sumber pertunjukan yang menjadi objek kajian dalam penelitian ini.

\section{Hasil dan Pembahasan}

Lakon ludruk yang sering dibawakan oleh Lerok Anyar adalah cerita Sawunggaling yang menceritakan tokoh Jaka Berek atau Sawunggaling yang dilahirkan sebagai simbol perjuangan pemuda Surabaya terhadap kolonialisme pada masa penjajahan Belanda. Pertunjukan Ludruk Lerok Anyar masih menggunakan struktur pertunjukan konvensional yaitu terdapat pembukaan/tari remo, atraksi bedayan, dagelan, dan lakon/cerita ludruk (Kasemin, 1999). Semua peran perempuan dalam pertunjukan Lerok Anyar dimainkan oleh para waria.

Lerok Anyar juga mempunyai aturan sendiri dalam memunculkan waria untuk menarik penonton, ada yang dimunculkan sebagai selingan saja, untuk menari dan nembang, ada pula yang menempatkan saat menari remo, dagelan maupun pemainnya. Tidak menampik, bahwa kemunculan waria waria ludruk ini sangat menarik minat penonton pria dewasa. Penonton pria lebih bergairah dan berhasrat untuk menonton pemain ludruk waria ini dengan polesan merah pada bibir dan pipi, mepertunjukkan payudara montok, dan pantat yang besar serta tidak lupa menunjukkan wajah cantik mereka. Selain itu pula pemain ludruk waria ini juga lebih luwes dan berani daripada pemain ludruk perempuan asli. Hal ini juga lah yang menarik penonton untuk berbondong-bondong dalam menyaksikan kesenian ludruk.

Kehadiran waria di lingkungan ludruk menjadi unsur yang sangat ditunggu oleh penonton dan penikmat ludruk. Keberadaan waria bagaikan pusat gravitasi yang sangat menarik bagi semua kalangan yang hadir untuk menonton pertunjukan ludruk. Suka atau tidak suka, senang atau tidak kehadiran mereka inilah yang selalu ditunggu oleh penikmat kesenian ludruk yang hampir tergerus oleh modernisasi zaman. Mereka adalah penerus budaya yang kini kian ditinggalkan oleh penikmatnya.

\section{Tubuh dan Identitas Gender Tandhak Ludruk sebagai Objek Komodifikasi}

Politik tubuh perempuan dikontruksi dan diproduksi secara terus-menerus dalam pertunjukan ludruk. Citra tubuh perempuan cantik, sexi dan indah digunakan untuk kepentingan para waria dan pemilik kelompok Ludruk Lerok Anyar. Para waria mengkontruksi tubuh laki-lakinya menjadi tubuh perempuan sebagai seorang tandhak ludruk. Para waria merubah penampilan fisik mereka mulai dari ujung kaki sampai ujung kepala. Membentuk rambut dengan model yang berbeda-beda sesuai mode, merias wajah mereka dengan sangat halus, menggunakan perhiasan seperti anting, kalung, gelang tangan, gelang kaki, memakai aksesoris rambut. Kemudian, menggunakan kebaya yang ketat berwarnawarni, jarit yang indah, memakai hils yang tinggi dan tidak lupa mewarnai jari-jari mereka dengan cat kuku. Pada bagian payudara dan pantat dibuat terlihat besar, ada yang suntik silikon dan ada yang mengganjalnya dengan gabus dan kain. Para waria tidak hanya melakukan perubahan terhadap tubuh fisiknya saja namun juga merubah gaya berjalan, nada suara dan gerakan-gerakan yang identik dengan gaya 
perempuan sungguhan. Iin salah seorang tandhak Ludruk Lerok Anyar mengatakan bahwa dia dan teman-temannya sangat perlu merubah bentuk tubuh laki-lakinya menjadi tubuh perempuan.

lho...yo penting to mbak, lha nek ra dandan opo yo iso ketok ayu? Nek ra nganggo gincu nek yo ketok pucet kaya mayet, lha nek ra nganggo bedak yo ketok buluk, nek rambut e ra dimodel yo elek. Lha nek ndapuk ludruk ngene ki nek kudu ketok ayu-ayu, nek ora ayu ora payu mbak, Nek ora disumpeli ora ketok seger, arep suntik yo larang hehehe, awak ndewe seneng nglakoni kaya ngene mbak, profesi nandhak iki yo wes suwe, melu ludruk ngene ki dadi iso dikenal akeh uwong karo nguri-uri kesenian tradisi.

Terjemahan: lho... ya penting mbak, kalau tidak dandan apa ya terlihat cantik? Kalau tidak memakai lipstik kan kelihatan pucat seperti orang mati, kalau tidak memakai bedak terlihat kusam, kalau rambutnya tidak dimodel ya jelek. Kalau main ludruk seperti ini harus terlihat cantik, kalau tidak cantik ya tidak laku. Kalau tidak diganjal (gabus/kain) tidak terlihat segar, mau suntik silikon ya mahal (ketawa). Kita semua disini senang melakukan rutinitas ini, profesi tandhak ludruk juga sudah lama, ikut ludruk kita jadi dikenal banyak orang (Iin, wawancara, 19 Agustus 2018).

Iin dan para tandhak Ludruk Lerok Anyar menggunakan citra tubuh perempuan untuk kepentingan menunjukkan identitas dirinya sebagai seorang perempuan cantik. Tubuh para tandhak membutuhkan pengakuan masyarakat atas gender femininnya. Para tandhak berkuasa atas tubuh laki-lakinya membuat tubuhnya menjadi patuh untuk dirubah menjadi tubuh perempuan guna kepentingan pengakuan identitas gender mereka.

Hadirnya tubuh perempuan melalui peran para tandhak juga sangat dibutuhkan untuk keberlangsungan kelompok Ludruk Lerok Anyar. Pertunjukan ludruk tidak akan berarti tanpa hadirnya penonton, kemunculan para tandhak menjadi daya tarik paling besar terhadap kehadiran penonton. Lakuan aksi yang dilakukan para tandhak mampu menghibur penonton. Kecantikan dan keluwesan berjoget para tandhak juga menjadi bagian yang ditunggu para penonton khususnya penonton laki-laki. Komodifikasi tubuh perempuan yang dilakukan para tandhak dengan menghadirkan bentuk tubuh perempuan cantik membawa keuntungan bagi kelompok Ludruk Lerok Anyar. Semakin banyak tandhak dengan paras cantik, jogetan luwes dan suara yang indah, semakin banyak pula orang yang akan menanggap kelompok Ludruk Lerok Anyar. Marsam Hidayat, pimpinan Ludruk Lerok Anyar mengatakan bahwa selain dari konsep garapan sutradara yang baik, kemunculan para tandhak juga menjadi daya tarik penonton sebab itu ciri khas dari Ludruk Lerok Anyar.

Penonton itu sangat senang dengan kehadiran para tandhak mbak, apalagi tandhak-tandhak kami itu terkenal luwes saat nembang, njoget dan juga cantik-cantik. Lerok Anyar kurang lebih ada 10-20 waria sebagai tandhak, kemunculannya berdasarkan kebutuhan dan permintaan penanggap dan konsep sutradara. Mama Chandra ini dulu pernah mendapat gelar primadona tandhak ludruk di Surabaya (Marsam Hidayat, wawancara, 19 Agustus 2018).

Para tandhak dan Kelompok Ludruk Lerok Anyar berkuasa atas citra tubuh perempuan dengan merubah tubuh laki-laki para waria dengan tubuh perempuan untuk mendapatkan keuntungan masing-masing. Para tandhak diakui identitas keperempuanannya di atas panggung oleh masyarakat dan kelompok Ludruk Lerok Anyar akan tetap dilirik dan disukai masyarakat. 


\section{Identitas Gender pada Tubuh Tandhak: Mime, Gerak dan Gesture}

Para tandhak Ludruk Lerok Anyar melakukan serangkaian gerak dan gesture keperempuanan secara terus menerus dan berulang-ulang. Gerak dan gesture keperempuanan para tandhak dapat dilihat dari gerak tari bedhayan, saat melakukan kidungan jula-juli dan lakuan aksi selama pertunjukan. Pola gerak bedhayan menyerupai pola tarian srimpi, para tandhak dengan sangat alus dan luwes menggerakkan bagian-bagian tubuh mereka. Tarian srimpi ini dibagi menjadi tiga bagian, yang pertama gerak maju gawang yaitu gerakan dilakukan seperti saat orang berjalan biasa saat menuju tengah panggung atau biasa disebut kapangkapang. Kedua gerak pokok, dalam gerak pokok ini para tandhak menyajikan inti dari tarian. Ketiga gerak mundur gawang, gerakan ini merupakan kebalikan dari gerak maju gawang, para tandhak mengakhiri tarian dan berjalan mundur meninggalkan panggung.

Gerak selanjutnya dapat dilihat saat para tandhak melakukan kidungan jula-juli. Para tandhak melakukan kidungan jula-juli sambil berjoget-joget bebas menggerakkan tubuhnya. Gerakan yang dilakukan mengikuti irama musik menurut irama dari panjak, semakin atraktif irama musiknya semakin aktif dan aktraktif juga gerakan para tandhak. Pada adegan ini para tandhak akan menyampaikan satu kidungan secara bergantian sesuai konsep sutradara dan permintaan penonton.

Para tandhak juga menunjukan tingkat keperempuananya melalui lakuan aksi dan mimik wajah saat menjadi peran perempuan. Enggar sebagai tokoh ibu dalam lakon Sawunggaling dapat terlihat layaknya seorang ibu yang penuh kasih serta lembut tutur katanya. Ekspresi mime yang ditunjukkan adalah ekspresi penuh kasih seorang ibu terhadap anaknya
Sawunggaling. Kemudian tokoh Pertiwi sebagai kekasih Sawunggaling dengan ekspresi lemah lembut dan terlihat sangat kemayu saat berdialog. Pertiwi secara konsisten menunjukan ekspresi-ekspresi gadis perempuan yang sedang kasmaran dengan tokoh Sawunggaling.

Untuk dapat melakukan serangkaian gerak, gesture tersebut para tandhak melakukan proses latihan yang dilakukan rutin setiap bulan. Latihan menari, latihan berperan dan latihan mengidung. Lakuanlakuan aksi yang dilakukan para tandhak Lerok Anyar melalui serangkaian gerak, gesture dan mime merupakan proses yang dilakukan secara berulang-ulang dengan konsisten untuk dapat menujukkan identitas keperempuanannya terhadap penonton.

\section{Identitas Gender pada Suara Tandhak: Kata dan Nada}

Tandhak Ludruk Lerok Anyar melalui merubah suara laki-lakinya menjadi menyerupai perempuan di dalam setiap pertunjukkannya. Perubahan suara tersebut terlihat pada kidungan dan juga pada saat adegan peran. Pada saat kidungan jula-juli, para tandhak memiliki karakter suara masing-masing. Mama Chandra dengan suara lembutnya, Wiwik dengan suara sengaunya, Indah dengan suara melengking dan tandhak-tandhak yang lain dengan suara khasnya masing-masing. Tandhak Lerok Anyar melakukan proses latihan suara secara terus-menerus untuk dapat menirukan suara sinden pada umumnya, latihan yang dilakukan adalah latihan nembang dan juga latihan vokal perempuan.

Sebelum ada job manggung, kami melakukan latihan rutin untuk menari, menyanyi dan acting mbak. Jadi, kalau sewaktu-waktu ada panggilan job kami sudah siap (Chandrika, 2018).

Identitas keperempuanan para tandhak tampak juga pada kata disetiap dialognya, tampak pada nada desahan dan intonasi 
suara. Berikut ini adalah contoh dialog Enggar saat berperan menjadi ibu Sawunggaling:

Ibu: lho... anakku... cung... kepiye cung anggonmu ngolek i bapakmu?

Sawunggaling: mergo pangestune sampeyan, aku ketemu marang bapak. Sepisan, mulihku mergo kepingin nguwei kabar yen aku uwes iso nemok ke bapakku, kaping pindone aku njaluk pangestu biyung yen aku iso diakui dadi tumenggung yen bisa merjaya raja Maulana.

Ibu: cung... wong dijaga alus, dicolong jagung lho nak, kon ate dipateni nak, ojok... ojok budal yo nak, temanan ora usah dadi tumenggung ora opo-opo nak.

Sawunggaling: ora biyung... aku wes janji marang bapak yen bakal nyekel raja Maulana, aku pangestonono Biyung... tak budal

Ibu: yen panven kepinginan mu wes manteb, biyung ora iso opo-opo cung... iyo tak pangestuni, tak timbul supaya slamet ya cung ya... (melangkahi tubuh Sawunggaling selama tiga kali).

Enggar dalam adegan di atas sangat menjiwai perannya menjadi seorang ibu, terlihat dari nada, intonasi suara dan kata yang diucapkan.

Mama Chandra saat berperan menjadi istri dari paman Sawunggaling:

Suami: ngene ki wong lanang wes jelas cepak nesune, mosok dikongkon budal belanja ning pasar, budal teko yahmono sampek yahmene durung bali, iki ning pasar opo minggat?

Istri: (muncul dari arah penonton) kuarang ajar.... Kurang ajar... nek enek wong wedok ayu ning ndalan kog dicoel, isin aku ngene ki isinn..... mene-mene emoh aku ning pasar kang emohh....masane mulai ko gang kono mau ditutke terus

Suami: kon iku lapo muring-muring ndek latar iku?

Istri: aku lho isin kat mau ditotno karo wong lanang, ngene ki lho nek wong wedok mlaku dewe...
Mama Chandra juga terlihat menguasai perannya sebagai seorang istri, sangat luwes. Dialog-dialog yang disampaikan para tandhak dalam perannya merupakan penggambaran atas diri mereka yang sesungguhnya. Para tandhak berusaha semaksimal mungkin untuk dapat menjadi figur perempuan sesuai peran masingmasing. Masyarakat mengidentifikasi para tandhak sesuai dengan sex biologisnya, maka dari itu para tandhak berusaha melakukan serangkaian cara melalui peran untuk dapat meyakinkan masyarakat bahwa mereka adalah perempuan.

2. Identitas Gender pada Artistik Tandhak: Make Up, Tata Rambut dan Kostum

Tandhak Ludruk Lerok Anyar tidak bisa terlepas dari peranan make up, kostum, dan gaya rambut. Para tandhak akan merias wajah mereka dengan sangat alus agar terlihat cantik. Setiap tandhak memiliki perlengkapan rias pribadi, lengkap dari foundation, bedak tabur, bedak padat, eye shadow, blass on, bulu mata, mascara, eye liner, lipstick dengan warna-warna terang (merah, jambon, maroon, dan orange), pensil alis serta lengkap dengan aplikator untuk make up. Para tandhak juga memiliki bentuk sanggul, sepatu tinggi, jarit dan kebaya yang berbeda-beda. Mereka membutuhkan waktu sekitar satu samapai dua jam sebelum pertunjukan dimulai untuk melakukan proses rias.

Mba Retno, salah seorang tandhak sangat rapi dan halus saat mengaplikasikan kemampuan merias wajahnya. Pertama, melapisi kulit wajahnya dengan foundation (alas bedak), kemudian dilapisi lagi dengan bedak padat sampai terlihat halus, menggambar alis dengan sangat hati-hati, memakai eye shadow di bagian kelopak matanya dengan warna sesuai kesenangan masing-masing tandhak, tidak lupa menggunakan eye liner dan mascara untuk 
membuat bulu matanya mejadi lentik, memberikan warna merah pada bagian pipi dengan blas on, kemudian memfinising dengan dilapisi bedak tabor agar hasil riasan terlihat halus dan rapi dan yang terakhir memakai gincu warna merah.

Setelah bagian wajah selesai dirias, Retno menyanggul bagian rambut. Bentuk sanggul disesuaikan dengan selera masingmasing tandhak. Ada yang memakai sanggul modern dengan model yang bermacammacam dan ada yang menggunakan sanggul jawa seperti yang dipakai Retno. Pada bagian sanggul ini butuh ketelatenan dan kesabaran karena tidak semua rambut mudah untuk dibentuk. Setelah selesai menyanggul, Retno berganti pakaian menggunakan kebaya brokat warna merah beserta dengan jarit dan slendang kecilnya. Para tandhak mengganjal bagian pantat dan payudara mereka dengan busa atau pun kain untuk membuat volumenya tampak besar. Tidak lupa juga menggunakan perhiasan (anting, kalung, gelang kaki, bros) dan juga sepatu tinggi untuk menambah kecantikannya. Begitupun dengan para tandhak yang lain juga melakukan proses yang sama.

Semua proses make up, kostum dan tata rambut yang dilakukan para tandhak adalah untuk menunjukkan tingkat kefemininannya. Para tandhak yang secara sex biologinya laki-laki merubah bentuk tubuhnya menjadi tubuh perempuan secara berulang-ulang guna mendapat pengakuan atas identitas keperempuanannya.

\section{Identitas Gender dalam Pertunjukan Ludruk Lerok Anyar}

Kelompok Ludruk Lerok Anyar melalui pertunjukannya menghadirkan para waria di atas panggung sebagai seorang tandhak ludruk. Tandhak yang secara sex biologis adalah laki-laki merubah tubuhnya melalui nada suara, gesture, dan make up serta kostum menjadi seperti seorang perempuan. Para tandhak cenderung menunjukkan penanda-penanda gender yang tampak melalui penampilan tubuh. Misalnya ketika salah seorang tandhak menceritakan tentang kebiasaan para tandhak yang berhubungan dengan penampilan dan atribut fisik, kebiasaan berdandan, kepedulian menata dan menyisir rambut serta pilihan pakaian yang digunakan menunjukkan sisi keperempuanan mereka.

Identitas gender dalam pertunjukan Ludruk Lerok Anyar merupakan sebuah hal yang koheren, terlihat pada identifikasi para tandhak ludruk terhadap gender dan seksualitas yang bukan sebagai biseksual maupun homoseksual, juga bukan sebagai heteroseksual. Para tandhak ludruk secara jelas menyebut identitas mereka sebagai feminine bukan maskulin, di mana gender dan seksualitas bagi mereka adalah sebuah instabilitas. Identitas menjadi sebuah yang tidak pasti, karena para tandhak menempatkan identitas sebagai sebuah hal yang dapat diubah, sebagai sebuah proses criss-crossing (Beasley, 2005).

Keperempuanan tandhak Ludruk Lerok Anyar tampak pada beberapa hal yaitu gesture, nada suara dan make up serta kostum. Gesture merupakan bentuk komunikasi non-verbal dengan aksi tubuh. Tandhak Ludruk Lerok Anyar menunjukkan identitas keperempuanannya melalui gerakan-gerakan non-verbal secara konsisten di atas panggung. Gerakan tangan yang lemah gemulai, perpindahan kaki maju mundur seperti seorang penari disertai geolan pada pinggul dan dada. Satu contoh pada bagian Tari Remo yang dimainkan oleh para tandhak terdiri atas tiga bagian: menari di tengah panggung, berjalan mengelilingi panggung, dan melakukan sembah secara anggun saat tirai diturunkan. Selama bagian pertama, kaki para tandhak digoyanggoyangkan, telapak kakinya mengikuti irama gamelan, sehingga sebuah gelang krincing di kaki mereka berbunyi berirama, 
sementara tangannya bergerak secara alus, menarik selendangnya, dan meletakkannya secara lembut di atas pundak. Para tandhak menyandarkan tangan mereka di paha, membalik lengan bagian bawah dan menggerakkan pergelangan tangan sambil berjalan memutar. Para tandhak memegangi selendangnya dan kemudian memutar tangannya. Semua gerakan yang dilakukan para tandhak menunjukkan sikap alus dan kelembutan yang biasa dilakukan perempuan saat menari.

Pengidung berusaha agar terlihat seperti seorang wanita yang alus. Berpenampilan seperti seorang sinden, para tandhak mengidung, bersuara soprano, dengan suara yang agak sengau. Tampaknya ada sedikit peran diafragma dalam suara tersebut. Para tandhak akan melakukan kidungan lebih dari satu tembang secara bergantian dan secara konsisten menjaga agar suara yang mereka keluarkan terdengar seperti suara sinden pada umumnya.

Selain melalui serangkaian gerak, gesture serta nada suara, para tandhak Ludruk Lerok Anyar menunjukkan tingkat kefemininan mereka melalui make up dan kostum. Berikut adalah proses para tandhak saat sedang melakukan make up sebelum pementasan dimulai. Para tandhak membawa peralatan make up lengkap beserta kostum yang akan digunakan saat pertunjukan. Para tandhak berusaha merias wajah mereka semaksimal mungkin, menggunakan sanggul dan kostum serapi mungkin agar terlihat cantik di atas panggung. Mereka merubah tubuh lakilakinya untuk menunjukkan keperempuanan dalam diri para tandhak melalui gesture yang lemah lembut dengan gerakan ringan, nada suara yang melengking menyerupai perempuan serta make up dan kostum.

Rangkaian pertunjukan itu baik sebelum maupun saat pentas, semua yang mereka lakukan untuk menunjukkan tingkat ke feminiman mereka kepada penonton melalui kehalusan kulit, kegemulaian gerak, dan kelembutan suara. Para juri menurut Butler mencakup teman kita, orang tua kita, media dan sebagainya maka, penonton pergelaran Ludruk Lerok Anyar dalam acara hajatan di Desa Dadapan, Telagarejo Kabupaten Malang adalah bagian dari juri yang terdiri dari sanak saudara, warga kampung dan para undangan. Mereka yang akan melakukan penilaian terhadap penampilan para tandhak di atas panggung untuk membuktikan seberapa besar tingkat kefemininan atau kemaskulinan mereka. Penonton Ludruk Lerok Anyar sebagian besar adalah penonton laki-laki, hal tersebut dikarenakan beberapa factor. Pertama, pertunjukan yang dimulai malam hari sehingga lebih banyak penonton laki-laki dibandingkan dengan penonton perempuan. Kedua, ketertarikan penonton laki-laki lebih besar terhadap penampilan para tandhak Lerok Anyar yang sudah terkenal cantik (Marsam Hidayat, wawancara, 19 Agustus 2018).

Penonton Ludruk Lerok Anyar dapat menyaksikan pergelaran ludruk dimanapun (tidak hanya pada kursi undangan) karena memang tempat pergelaran di halaman rumah dan terbuka untuk umum. penonton banyak yang menyaksikan dari sudut jalan dan samping panggung tepat para pemain berlalu-lalang sebelum pergelaran dimulai.

Pergelaran diawali dengan tari remo putri, dilanjutkan tari remo putra, bedhayan, kidungan dan yang terakhir masuk pada lakon/cerita. Pada saat tari remo dan para tandhak naik ke panggung sorak tepuk tangan penonton mulai terdengar. Antusias dari penonton yang lumayan rame membuat para tandhak semakin ingin memperlihatkan kelincahan mereka dalam menari remo. Setelah rangkaian tari remo selesai dilanjutkan dengan bedhayan dan kidungan. Para waria yang tadinya menggunakan kostum remo berganti menggunakan kebaya brokrat dan jarik untuk mengidung dan 
bedhayan. Penonton laki-laki yang berada di samping panggung tak henti-hentinya memandang tubuh para tandhak dari ujung kaki sampai ujung kepala karena memang terlihat sangat cantik. Salah seorang penonton, Parmanto dengan tanpa ragu mengulurkan tangan kepada para tandhak yang menggunakan hils tinggi untuk membantu mereka menaiki tangga. Penonton menyaksikan dengan penuh suka cita pergelaran dari awal hingga akhir dengan sering kali memberikan tepuk tangan dan siulan-siulan.

Lima dari tujuh orang penonton lakilaki serta tiga dari lima penonton perempuan saat diwawancarai peneliti mengatakan bahwa memang para tandhak Ludruk Lerok Anyar telah berhasil mengkontruksi tubuh laki-laki mereka menjadi sangat perempuan terlihat dari gerak, gesture, make up dan kostum. Penonton laki-laki maupun perempuan bahkan tanpa ragu memuji kecantikan para tandhak. Seorang penonton perempuan mengatakan bahwa kecantikan para tandhak ludruk tersebut mengalahkan kencantikan dirinya. " wahhh... ayu-ayu mbak, cantik, nek dandan alus-alus, nek disawang aku karo tandhak-tandhak itu kalah cantik" (Wiji, wawancara, 19 Agustus 2018).

Serangkain gerak, gesture, perubahan nada suara serta pemakaian make-up kostum yang dilakukan para tandhak ludruk adalah proses imitasi/penggulangan yang dilakukan secara terus-menerus untuk membentuk efek yang benar-benar alamiah bahwa mereka adalah perempuan di atas panggung. Para juri yang tidak lain adalah penonton telah membuktikan tingkat kefemininan para tandhak Ludruk Lerok Anyar seperti yang dikatakan oleh Butler. Panggung ludruk melalui kelompok Ludruk Lerok Anyar memberikan ruang bagi para tandhak untuk menunjukkan identitas gender femininnya.

\section{Tubuh dan Sensualitas Tandhak dalam Pertunjukan Ludruk}

1. Tubuh Tandhak dan Hasrat Kaum Lakilaki

a. Hasrat Sensualitas Laki-laki

Hasrat sensualitas adalah keinginan atau dorongan untuk mendapatkan kepuasan secara seksual, baik secara nyata maupun hanya sebatas fantasi. Hasrat sensualitas laki-laki berarti adalah keinginan lelaki untuk mendapatkan kepuasan seksual melalui objek perempuan, bisa melalui rangsangan secara langsung maupun tidak langsung. Rangsangan langsung didapatkan melalui kontak fisik antara laki-laki dan perempuan. Rangsangan tidak langsung dapat melalui suara, gambar, melihat sebuah video, maupun pertunjukan yang akan membuat para lelaki berimajinasi dan membayangkan bahwa mereka telah berada pada keadan tersebut sehingga pada akhirnya terpenuhilah hasrat sensualitasnya melalui rangsangan tidak langsung tersebut. "yo luwes mbak narine, ngremo yo luwes, ngidung yo luwes, seger-seger mbak" (Parmanto, wawancara, 19 Agustus 2018).

Pada kasus ini adalah hasrat penonton laki-laki terhadap waria sebagai tandhak ludruk dalam kelompok Ludruk Lerok Anyar. Para tandhak telah mengkontruksi tubuh lelakinya menjadi tubuh perempuan layaknya seorang pesinden. Kecantikan dan kemolekan tubuh tandhak di atas panggung yang tidak bisa dijumpai dalam realitas keseharian membuat penonton laki-laki ingin memilikinya. "Seger...segeer mbak, kalau dia perempuan sungguhan, sudah saya jadikan istri " pernyataan dari salah seorang penonton bernama Sabar berusia 50 tahun. Ketertarikan laki-laki terhadap para tandhak Ludruk Lerok Anyar sudah mulai terlihat pada saat para tandhak merias wajah. Nardi (47 tahun) secara diam-diam mengintip dari pintu belakang saat para tandhak sedang melakukan rias. Saat itu pun Wiwik yang hendak berganti kostum nyloteh "mbok ra sah inceng...inceng mas, mengko timbilen mripatmu", sontak membuat Nardi cengar- 
cengir menahan malu dan pergi meninggalkan tempat.

Saat diwawancarai oleh peneliti mengapa Nardi ingin melihat proses rias para tandhak, dia hanya menjawab " $a y u$ mbak, eh yo mergo penasaran ae ding mbak". Rasa penasaran Nardi secara tidak langsung menunjukkan ketertarikannya terhadap tandhak Ludruk Lerok Anyar. Selain Nardi tampak pula beberapa orang laki-laki yang mondar-mandir di depan pintu yang ingin melihat pula proses rias namun enggan untuk masuk. Saat peneliti mengambil gambar satu-persatu dari tandhak ludruk yang sudah selesai rias, peneliti tidak sengaja mendengar percakapan bapak-bapak dan seorang perempuan paruh baya yang duduk di depan pintu samping panggung mereka membicarakan tentang perubahan tubuh tandhak.

Saat beberapa tandhak ke luar dari ruang rias menuju panggung, terdengar clotehan dari tukang sound "ati-ati yuu, bokongmu kesenggol" sambil tertawa setengah menggoda. Sontak Wiwik menyahut, "seng kesenggol lak yo malah demen" dan melanjutkan langkahya naik panggung. Para tandhak memiliki hasrat menjadi perempuan melalui serangkaian gerak, gesture, make up dan kostum. Hasrat menjadi perempuan dengan mengkontruksi tubuh laki-lakinya agar terlihat layaknya pesinden menimbulkan dorongan kepada penonton laki-laki untuk tidak berhenti memandang dan mengimajinasikannya. Menyaksikan tubuh para tandhak fantasi keindahan tubuh perempuan dapat diimaginasikan. Penonton dengan leluasa dapat mengimajinasikan sosok-sosok perempuan, seperti yang ada di angan-angan para penonton laki-laki, dan seolah-olah membuat hasrat sensualitas mereka terpenuhi melalui bentuk tubuh para tandhak ludruk.
b. Tubuh Tandhak sebagai Objek Sensualitas

Saat citra menjadi seksualitas, saat wajah menjadi sensualitas dan saat perempuan menjadi objek melalui bahasabahasa panggung yang selama ini kita kenal (lighting, bahasa, pengambilan gambar) sehingga akan lahir kata representasi. Komodifikasi dapat digambarkan sebagai perubahan fungsi/guna menjadi nilai tukar (Mosco, 2009) yang kemudian menjadi cara pandang dimana media sebagai salah satu alat untuk menyampaikan informasi dan edukasi kepada masyarakat luas memiliki peranan yang sentral. Media mampu memberikan efek rangsangan yang mengarah pada pola konsumsi masyarakat sehingga tercipta rasa ingin memiliki. Tidak jarang untuk kepentingan komersialitas sosok perempuan dijadikan objek dalam konten media.

Komodifikasi tubuh tandhak menghasilkan objektivikasi sekaligus subjektivikasi. Sebagai objek, tandhak mengalami objektivikasi atas tubuhnya, namun sebagai subjek, ia dapat mengomodifikasi tubuhnya untuk memperoleh keuntungan bagi dirinya sendiri. Penggunaan kebaya dan jarit ketat yang memperlihatkan belahan dada, pantat yang besar, bibir bergincu merah, serta pemerah pipi yang tebal oleh para tandhak adalah bentuk komodifikasi atas keindahan tubuh perempuan. Namun, komodifikasi tidak akan terjadi tanpa rasionalisasi tindakan laki-laki kepada tandhak dan tubuhnya. Tidak hanya melalui pandangan dan rasionalisasi tindakan laki-laki, komodifikasi terhadap tubuh tandhak dapat dilakukan dengan basis modal. Namun, profesi yang dijalankan oleh seorang tandhak tidak selalu menjadi faktor penentu apakah tubuh tandhak tersebut dikomodifikasi.

Faktor lainnya yang dapat digunakan untuk menentukan apakah tubuh tandhak terkomodifikasi oleh kepentingan yang lain atau tidak adalah penggunaan tubuh tandhak 
dengan tujuan untuk menarik perhatian penonton semata, intervensi atas kostum, sikap, ataupun gerakan tandhak dengan tujuan untuk penjualan suatu produk yaitu lakunya kelompok Ludruk Lerok Anyar. Namun demikian, di sisi lain tandhak sadar bahwa tubuh mereka adalah realitas dari keindahan manusia, mereka menjadikan tubuhnya sebagai aset. Aset ini tentu saja dapat 'dijual' atau digunakan untuk mendapatkan keuntungan tertentu. Komodifikasi terhadap tubuh tandhak dalam hal ini dapat dilihat dalam dua sisi, sebagai objek ataupun subjek. Sebagai objek, tandhak mengalami objektivikasi atas tubuhnya sedangkan sebagai subjek, tandhak melakukan subjektivikasi atas tubuhnya. Sebagai objek, tubuh tandhak adalah korban komodifikasi dari kekuatan lain di luar tubuh si tandhak itu sendiri, tetapi sebagai subjek, tandhak justru menjadi pelaku komodifikasi.

Sebagai pelaku, tandhak melakukan hal tersebut secara sadar. Ia tidak lagi berada dalam posisi yang lemah seperti ketika tandhak menjadi objek dan dikomodifikasikan, tetapi tandhak dalam hal ini memiliki posisi yang kuat untuk menjadi pelaku komodifikasi atas tubuhnya sendiri. Dalam dunia hiburan, penonton menjadi salah satu pihak yang memiliki peran signifikan dalam menentukan penampilan penghibur. Penampilan yang dipertontonkan oleh tandhak lebih menonjolkan penampilan fisik dalam balutan kebaya seksi dengan gerakan-gerakan menantang. Penampilan fisik para tandhak tersebut dikonstruksi melalui definisi tubuh yang cantik dan seksi dari para pemilik dan penonton tempat hiburan. Penonton ludruk yang sebagian besar laki-laki ini mengakui bahwa tandhak menjadi komoditas yang sengaja dipertontonkan untuk menarik perhatian mereka.

Tubuh tandhak yang memuat cita rasa estetis bagi laki-laki dikomodifikasikan sesuai dengan tuntutan laki-laki sebagai penonton. Di sinilah komodifikasi tubuh tandhak, pencitraan dan penggunaan tubuh tandhak sejak dahulu hingga kini telah mengalami evolusi yang mencengangkan. Berbagai alasan dikemukakan, mulai dari alasan ritual hingga komoditas. Namun sepertinya motif komoditas masih terus bertahan hingga kini.

Tubuh para tandhak yang indah dan seksi digunakan sebagai kepentingan modal dalam aktivitas ekonomi industri oleh kelompok ludruk melalui tanda-tanda yang terfragmen dan melalui hasrat laki-laki atas tubuh tandhak untuk memperoleh keuntungan ekonomi. Fragmen-fragmen tubuh tandhak melalui pose dan gerakan yang menantang menjadi objek yang 'dipuja' dan memiliki pesona tersendiri dalam menghasilkan rangsangan, hasrat, dan citra tertentu. Keseksian dan sensualitas tubuh para tandhak menjadi atribut bisnis yang menarik. Ketika tubuh, bagian tubuh, atau fungsi seksual dari tubuh dipisahkan dari totalitas kedirian seorang tandhak, maka praktik objektivikasi seksual atas tubuh tandhak itu dilakukan.

Dalam bidang lain penggunaan tubuh perempuan dieksploitasi melalui berbagai bentuk yang menghasilkan pemikiranpemikiran negatife dan merangsang hasrat penontonnya. Tubuh perempuan dikontruksi sedemikian rupa untuk kepentingan banyak hal, melalui media iklan, film, dan foto-foto di majalah dewasa yang mempertontonkan kemolekan tubuh perempuan untuk membranding produk masing-masing perusahaan.

Dalam seni pertunjukan tradisi, pertunjukan tari Jaipong, Tayub, Gandrung, Lengger, tubuh perempuan sangat mendominasi. Tari Jaipong, Tayub dan Gandrung tubuh perempuan digambarkan dengan paras yang cantik, tubuh yang molek, gerakan-gerakan tari yang sangat dikagumi lelaki. Begitupun pada lengger 
lanang dan ludruk, merekontruksi tubuh laki-laki menjadi tubuh perempuan cantik, molek, bahenol, sangat alus yang tidak kalah digemari oleh penonton laki-laki.

Tubuh perempuan melalui peran para tandhak merupakan salah satu bentuk pemanfaatan dan komodifikasi tubuh perempuan. Para tandhak yang memiliki bentuk tubuh laki-laki mengontrol dan mengkontruksi tubuhnya menjadi bentuk tubuh perempuan. Mengontrol secara visual maupun naratif. Para tandhak mengkontruksi tubuh mereka untuk menunjukkan kesan sensual kepada penonton melalui pementasan kelompok Ludruk Lerok Anyar. Para tandhak merias wajah lelaki mereka dengan sangat halus hingga membentuk wajah perempuan cantik, menggunakan baju dan kostum perempuan, menggunakan sanggul yang besar dan halus, memakai perhiasan mulai dari anting, kalung, cincin dan jika perlu gelang kaki, mereka menggunakan hils yang tinggi dan tidak lupa dengan kuku-kuku mereka yang di cat dengan warna-warna merona (merah). Mereka melebih-lebihkan, menyesuaikan mode, dan menghadirkan kecantikan perempuan ke dalam objek tatapan yang menentramkan hati. Dalam genre klasik, tubuh perempuan adalah seksualitas yang menyajikan objek erotik bagi penonton lakilaki.

Aku kudu dandan apik mbak, pokok e sing enek nang awakku kudu dadi ketok mencorong, lek iso wong-wong podho delok aku kabeh iki lho aku sing sak tenane, iso jogged, ayu lan seksi rambutku tak model-model cek ketok ayu.

Terjemahan: (Aku harus dandan cantik mbak, apa yang ada di tubuhku harus bisa terlihat mempesona, kalau bisa orangorang melihat ini lah aku yang sebenarnya yang bisa melakukan semua, bisa menari, cantik, seksi, rambutku aku bikin agar terlihat cantik) (Iin, wawancara, 19 Agustus 2018).
Hasrat para tandhak ludruk yang ingin menjadi perempuan membuat mereka memilih untuk mengkontruksi dan mengontrol seluruh bagian tubuh laki-laki mereka. Para tandhak ludruk tidak hanya merubah dan menaklukkan melalui bentuk tubuh fisik namun juga melalui gerak, gesture dan suara. Mereka menjaga konsistensi untuk dapat terlihat seperti perempuan tidak hanya di atas panggung namun juga dalam kehidupan keseharian. Mereka menirukan feminitas perempuan, merubah nada suara menjadi sengau, serak, ada yang halus dan melengking, gaya bicaranya kemayu, cara berjalannya sengaja dibuat-buat untuk mendapatkan kesan sensual pada tubuhnya. Para tandhak dan tubuh perempuannya berfungsi sebagai objek erotik bagi sebagian penonton lakilaki yang dapat memperoleh kepuasan sensual melalui tatapan.

2. Tubuh dan Nilai Sensualitas

a. Sensualitas Tubuh pada Tandhak: Mime, Gerak dan Gesture

Tubuh perempuan seni tradisi yang penuh kelembutan tergambar dalam tubuh para tandhak Ludruk Lerok Anyar. Gerak lehernya, lirik matanya, bahkan cara tandhak menggoyangkan pundak akan memukau laki-laki dewasa yang menontonnya. Para tandhak melakukan kidungan jula-juli sambil bersuka ria berjoget-joget menggerakkan tubuhnya. Adegan kidungan jula-juli dan lawakan merupakan bagian dimana para penonton dan pemain bersuka ria berjoget. Tirai dibuka lalu tampil satu lawak sambil mengucapkan kata-kata "yok opo rek-rek malam minggu sepi ngene, tak ngidung ae cek rame". Tiba-tiba dari bangku penonton seseorang berdiri melemparkan bungkusan dan meminta gending-gending. Bungkusan dibuka kemudian salah satu pelawak meminta salah seorang tandhak untuk mengidungkan gending permintaan penonton. Retno salah seorang tandhak 
bergerak lemah gemulai sambil mengidung, yang lainnya berjoget-joget, kadang para tandhak yang lainnya mengikuti irama dari panjak (pengrawit) yang kadang berirama campursari, jaipongan dan dangdutan. Para tandhak mengikuti irama dengan merefleksikan menurut irama dari panjak, misalnya, irama jaipongan maka mereka akan bergoyang jaipongan, irama campursari bergoyang campursari dengan gaya beksan tayub.

Gerakan-gerakan para tandhak terkadang mendapat respon dari penonton. Penonton yang tertarik berjoget-joget di sekitar bangku duduknya meskipun penonton yang lainnya menonton dan mengikuti gerakan tandhak dengan hanya duduk di bangku. Adegan ini bisa menjadi bagian yang panjang dan pendek tergantung pada permintaan atau lemparan kertas dari penonton. Gerakan para tandhak menimbulkan rangsangan bagi penonton, Mulyono penggiat ludruk yang telah menonton mulai tahun 80-an pada saat adegan ini, kebetulan duduk berdampingan satu bangku dengan peneliti memberi komentar, "kidungan dan gerakan para tandhak itu luwes, jadi saya suka menontonnya", bagi Mulyono, gerakan para tandhak di atas panggung dianggap luwes melebihi perempuan sesungguhnya juga ada kenakalan-kenakalan spontan dalam gerakan-gerakan tubuh. Kenakalan spontan dalam gerakan dibangun karena adanya interaksi dengan penonton. Dalam adegan ini para tandhak menunjukkan gerakangerakan yang terkadang tampak eksotik dan erotis.

b. Sensualitas pada Suara Tandhak: Kata Dan Nada

Melalui suara desahan, kata-kata yang vulgar pada beberapa adegan, serta nada suara yang sengaja dibuat seksi oleh para tandhak untuk dapat menunjukkan kesan feminin dan sensual pada penonton.
Penonton menikmati setiap kata dan nada yang diucapkan para tandhak.

Suara kidungan yang terdengar dari ruang make up membuat peneliti penasaran, apakah itu suara yang keluar dari kaset yang dimainkan tape recorder atau suara asli yang keluar dari suara para tandhak, suara itu agak tinggi dan sengau, peneliti sontak berdiri dan melangkah menuju arah suara.

Suara kidungan berkaitan dengan keinginan para tandhak dalam menunjukkan identitas gender serta menimbulkan kesan sensual. Lirik-lirik dalam kidungan yang keluar dari suara para tandhak tersebut merupakan bentuk dari pengungkapan bahwa tidak hanya melalui fisik tetapi dari suara para tandhak mencoba memberikan suatu imajinasi mengenai keinginan para tandhak agar disukai laki-laki. Percakapan tokoh Pertiwi (kekasih Sawunggaling) dan Emban Biyung:

Emban: gusti putri ngresakne nopo?

Pertiwi: kui lho yung... (nada suara manja)

Emban: kua...kui nopo? Lha kawet mau kog kua...kui...

Pertiwi: mosok ra ngerti to yung?

Emban: Bakso?

Pertiwi: $d u d u .$.

Emban: lha nopo? Rujak cingur?

Pertiwi: $d u d u$

Emban: eeee rujak cingur e kene enek seng enak lho, cingur e seng ngendang...

Pertiwi: lha opo iyo to yung? (ketawa manja)

Emban: enggih, saestu, dereng tau ngrasakno to? Seng ngendang wes tuo, cingur e alot...

Pertiwi: ya durung ( sambil tertawa)

Emban: lha... ngoten lho nguyu, kat mau kog sungkawa terus (sambil jalan dengan kaki mengangkak)

Pertiwi: yung... lha kog nek tindakan kaya ngono to?

Emban: menika kekatahen jamu gusti, kedah e jamu sari rapet malah didoline jamu sari benggang

Pertiwi: yung...yung... sak jane atiku ki nek yo sungkawa banget yung 
Emban: lha teng napa to? Enten nopo?

Pertiwi: kui lho yung, kang mas

Sawunggaling kui wes enek sesasi kog yo ora tilek-tilek rene to yung

Emban: woo.. dereng absen to?

Pertiwi: dereng yung... dereng...

Emban: wooo lha Sawunggaling kui lancing og terah lancing, pacare ning kene kog ra diendangi, wayah e nek rene terus aku seng nandangi...

Dialog di atas menggambarkan kegelisahan dan kesedihan Pertiwi yang sudah satu bulan tidak ditemui Sawunggaling. Adegan ini disajikan dengan penuh humor, tokoh Emban menanggapi setiap perkataan Pertiwi dengan kata-kata vulgar. Semakin vulgar kata yang diucapkan semakin heboh respon penonton.

Adegan 3 pada bagian percakapan Pertiwi dan Emban, Emban mengucapkan parikan (pantun berbahasa jawa) sambil berjoged diiringi oleh panjak:

Pertiwi: lho...lho... yung...yung... pie iki... ojo banget..banget too yung... eеe...eee...eeee, hayoo...hayoo... aku mau mula nek wes kondo ojo banget-banget... aduhhh hooh yung goyang seng penak yung,,, aduhhhh...

Emban: Mi... ngatemi... mi...ngatemi...

Mi ndekem o tak dekemi....

Meneng o... saben wengi nyawang kotang...

Pertiwi: lho... kog kotang to yungg...

Emban: lho.. lha pripun to ndoro?

Pertiiwi: konang uduk kotang yung...

Emban: wooo... lha nyat seng ngendang ki sentiment ra gelem ngandani...og.. engko tak rujak tenan kapok cingur e...

Emban: Rumiyen...rumiyen.... (sembari mengintip bagian payudara Pertiwi)

Pertiwi: Ngopo to yung?

Emban: Mboten... Mbotennn (menengok kembali sambil bergumam) aslii... ngonku no mung gombal...

Pertiwi: Ngopo to yung ketok e kog aku mbok rasani...

Emban: Mboten... kulo naming matur kalihan penonton umpami ndoro kula ngoten pancen ayuu, klambi kula niku naming gombal

Pertiwi: Tapi kog aku kaya krungu rasanrasan kui mau... Nyapo kog sajak e...

Emban: Mboten...mboten... mboten ndoro... (sambil memandangi lagi payudara Pertiwi)

Pertiwi: Nyapoo to yungg... Nyapo?

Emban: Mbotennn... (sambil berjalan dan ganti melihat payudaranya sendiri) lha ngonkuuu mung gombal

Pertiwi: Ojoo... rasan-rasan aku tho yung...

Emban: Mboten ndoro mboten ... (berjalan ke arah belakang sambil bilang susu...susu...susu...).

Adegan berikutnya adalah saat Sawunggaling datang menemui Pertiwi, Emban nyemoni (meledek) Pertiwi:

Emban: Kang mas... duh kang mas Sawunggaling... kulo kangen kalih njennegan ...kangmas...

Pertiwi: lhoo yung...yung... lha nek ngono kui atiku terus kepie?

Emban: Ooo lha menika sampun rawuh... tugas ipun emban nek kedah njagi ndoro nipun

Pertiwi: Heemmmm em terus?

Emban: Lha nggih saumpami ndoro nipun bade dahar niku emban e rumiyen lha mbok menawi enten racun e

Pertiwi: Ooo ngonooo...

Emban: Nggih dados nek kenek racun emban e rumiyen... lhaa pacaean nggih ngotennn emban $e$ sek seng nyicipi... mangke nembe ndorone ngoten...

Pertiwi: Kang masss... kog njenegan ora tau rene ki kepiye? Emban menirukan (kang mas... kang mas Sawunggaling njennegan niku pripun, kula sampun kangen banget kakang, kog kula mboten lajeng pen pelok, pen cium cup...cup... ngoten to...)

Tokoh Pertiwi kerap kali mengulang kata "aduuuh yung", lho..lho.. yung", eee...eeee" dengan nada suara kemayu dan sedikit mendesah. Dialog percakapan Pertiwi dan Emban jika menurut naskah 
tidak seperti itu, dialog tersebut adalah hasil pengembangan mereka sendiri secara sepontan di atas panggung. Dialog dengan menggunakan ungkapan-ungkapan saru menggugah respon penonton, mulai dari ketawaan, umpatan "dancok" dan lain-lain.

Para tandhak juga merubah nada suara mereka dari suara laki-laki menjadi suara perempuan yang halus. Setiap tandhak memiliki ciri khas suara yang berbeda-beda, ada yang sengau, tinggi melengking, mendesah, serak-serak basah dan halus lembut. Semua nada suara yang sengaja di buat para tandhak tidak hanya untuk menunjukkan identitas keperempuanan tetapi juga untuk menunjukkan kesan sensual pada para penonton.

c. Sensualitas pada Artistik Tandhak: Make $U p$, Tata Rambut, dan Kostum

Dalam sajian seni pertunjukan ludruk, peranan make-up dan kostum serta penataan rambut merupakan bagian paling penting bagi para tandhak untuk dapat mengubah penampilan dan meningkatkan rasa percaya diri. Mulai dari polesan wajah, bentuk sanggul, model dan warna kebaya, serta corak kain yang dipakai sengaja dipasang sedemikian rupa untuk memikat penonton, khususnya para penonton laki-laki yang tergila-gila oleh kecantikan, goyang pinggul, serta eksploitasi gerakan tubuh tandhak.

Secara umum make up dan kostum para tandhak menonjolkan kesan "khas" sensualitas. Untuk menonjolkan kesan sensual, masing-masing tandhak mempunyai cara khusus dalam hal menggunakan make up dan kostum. Antara lain, bentuk make up nya memberikan kesan menor seperti pada umumnya make up gaya panggung, menggunakan bedak yang dipoles berulang kali, pemerah pipi yang tebal, bulu mata lentik serta gincu bibir yang merah merekah layaknya mawar merah dan paling spesifik adalah bentuk sanggul para tandhak yang menggunakan sanggul besar layaknya sinden. Para tandhak pun tidak lupa mewarnai kuku-kuku mereka agar terlihat cantik saat menggerakkan tangan di atas panggung.

Para tandhak pada umumnya mengenakan kebaya serta kain dalam satu warna (merah, kuning, jingga, hijau, dan biru) yang dibuat dari bahan brukat, ataupun silk dengan bentuk kebaya ketat, serta bagian dada sedikit terbuka hingga kedua hiasan dadanya tambak sebagian menyembul. Begitupun kain bagian bawah, dibuat seketat mungkin yang menonjolkan bentuk pinggul dan pantat, seolah-olah membalut tubuh. Bagian depan kain dibuat belahan tinggi dengan wiru (lipatan-lipatan pada kain) agak banyak, sehinga apabila sedang melakukan gerakan-gerakan tertentu seperti melompat, menganggkang, mengangkat kaki, atau gerakan akrobat, kain akan terbuka lebar dan menampakkan sebagian betisnya.

Model seperti itu sangat membantu ruang gerak para tandhak agar gerakan seperti menggoyangkan pinggul dan lainlain bisa ditampilkan seleluasa mungkin. Ada kiat khusus untuk dapat menonjolkan tubuh yang seksi, serta bagian dada (payudara) agar tampak besar dan berisi, yaitu menyumpalkan kain dari saputangan, handuk, atau busa untuk menganjal bagian payudara. Sedangkan untuk menonjolkan pinggul dan pantat mereka menyumpal dengan bahan handuk kecil, atau busa yang ditempelkan pada celana dalam secara khusus. Ini semua merupakan usaha untuk tampak lebih menarik, selain wajah juga tubuh.

Seperti yang dijelaskan bunda Iin saat diwawancarai dia sebagai anggota tandhak Ludruk Lerok Anyar juga melakukan proses yang sama untuk dapat menimbulkan kesan sensual pada penonton, kesan cantik dan kesan feminin. 


\section{Hasrat Sensualitas Penonton: Antara Realitas dan Imajinasi}

Pada saat peneliti mengamati tanggapan penonton, melihat pertunjukan ludruk mereka cenderung melihat penampilan para pemain warianya. Penonton mempunyai alasan tersendiri mengapa mereka memperhatikan aktivitas para tandhak. Penonton beranggapan ceritacerita di ludruk dari tahun ke tahun sama. Maka mereka lebih senang melihat berbagai atraksi yang ditampilkan para waria dalam pergelaran. Tingkah laku penonton sangat menarik perhatian pada saat adegan-adegan dimana para tandhak mulai masuk panggung. Suasana sangat terasa sekali bahwa para penonton ingin melihat tingkah laku para tandhak dalam memainkan peran. Penonton secara tidak sadar mengeluarkan kata-kata "luwes, cantik, serta dancuk". Penonton terpesona menyaksikan aksi waria dalam mengidung dan berjoget, suara dan gerakan tubuhnya luwes menyerupai perempuan sungguhan.

Para pengidung waria yang seksi juga diteriaki penonton, katanya seperti "Merlyn Monroe" atau dengan suitan yang dimaksudkan untuk menggoda para tandhak. Setiap penonton memiliki tanggapan yang berbeda-beda mengenai tandhak ludruk, ada yang hanya membicarakan kecantikan, kehalusan suara dan jogetan sampai ada yang memiliki gairah nafsu. Bambang, yang sejak dulu giat menonton ludruk mengatakan bahwa dia sampai memimpikan salah seorang tandhak, ada yang sampai menginginkan tinggal satu rumah.

Penonton laki-laki dapat terpuaskan fantasi-fantasi erotisnya secara liar dengan memandang pemain waria. Pemain waria juga menunjukkan simbol "keterpisahan dari penonton dan penampilan alaminya" yang memberikan penegasan kepada penonton laki-laki, bahwa dia sama sekali tidak menawarkan kepuasan seksual secara real kepada penonton, namun penonton diberikan kebebasan untuk menikmati fantasi-fantasi seksualnya melalui kidungan dan jogetan tubuh yang dilakukan oleh para tandhak. Secara psikologi justru hal itu memberikan rasa penasaran yang tinggi, karena menjadikan penonton hanya dapat mengimajinasikannya.

Freud mengatakan bahwa alat kelamin yang merupakan anggota badan yang menawarkan kepuasan jarang sekali dianggap sebagai ayu. Kemungkinan yang lain, tepat karena pemain waria itu menyesuaikan diri dengan mode, yang tidak seperti kebanyakan wanita kongkret, menjadikan pemain waria itu sebagai super women. Ini bisa demikian baik karena wajah modis dari pemain waria membentuk semacam bayangan-bayangan sifat-sifat yang lebih feminin ketimbang para wanita yang sesungguhnya (beberapa laki-laki hanya ingin sebuah fantasi, bukan wanita yang sesungguhnya) maupun karena wajah modis pemain waria itu, yang tidak seperti setiap wanita kongkret manapun, bergabung menjadi satu citra dari "banyak wanita", atau paling tidak citra mengenai sifat-sifat yang umum bagi banyak wanita.

Penelitian langsung yang dilakukan peneliti menunjukkan bahwa lebih banyak penonton laki-laki dibandingkan dengan penonton perempuan. Berbagai respon dari penonton laki-laki membanjiri pementasan Ludruk Lerok Anyar pada saat para tandhak keluar, seperti siulan dan godaan lainnya. Tidak sedikit pula penonton laki-laki yang melihat pementasan dari samping panggung tepat di bawah para tandhak menari dan mengidung. Beberapa tandhak pun mencoba memberikan sinyal kepada penonton lakilaki yang berada di samping panggung melalui tatapan mata dan kemudian disambut hangat oleh beberapa penonton laki-laki dengan tatapan mata pula.

Melihat penampilan para tandhak dengan kecantikan dan kemolekan tubuh perempuannya membuat penonton laki-laki 
merasa terpuaskan. Penonton dapat dengan bebas membayangkan dan mengimajinasikan tubuh para tandhak sesuai dengan apa yang ada dipikiran mereka. "Yo ora ono mbak ning saben dina ne", Mulyono, salah seorang penonton mengungkapkan bahwa beliau tidak dapat menemukan perempuan-perempuan layaknya pesinden di kehidupan kesehariannya, melalui tubuh para tandhak di atas panggung ludruk, dia dapat mengimajinasikan tubuh perempuan sesuai keinginannya.

Berdasarkan pengamatan langsung yang dilakukan peneliti terhadap pola interaksi tandhak Ludruk Lerok Anyar dengan para penonton laki-laki , membuktikan bahwa para tandhak sengaja menghadirkan serangkaian gerak, gesture, perubahan nada suara, make up dan kostum untuk membangun imaginasi penonton lakilaki terhadap keindahan tubuh perempuan seksi dan cantik. Para tandhak sebisa mungkin menghindari interaksi langsung dengan penonton laki-laki, jika tandhak dan penonton bertemu malah akan membuyarkan imaginasi yang sudah diciptakan para tandhak terhadap penonton atas tubuhnya. Penonton hanya diperbolehkan membayangkan keindahan tubuh seksi para tandhak melalui fantasifantasi pikiran mereka. Tandhak adalah gambaran kesempuraan perempuan di dalam tubuh dan realitas yang salah.

\section{Simpulan}

Panggung pertunjukan ludruk melalui kelompok Ludruk Lerok Anyar mampu memberikan ruang bagi para waria untuk dapat menunjukkan identitas dirinya kepada masyarakat luas secara terbuka. Melalui serangkaian gerak, gesture, make up dan kostum waria menunjukkan kefemininannya di atas panggung. Tandhak Ludruk Lerok Anyar melakukan proses imitasi pada dirinya secara berulang-ulang sampai membentuk efek yang benar-benar nyata bahwa mereka adalah perempuan di atas panggung. Proses tersebut dilakukan melalui rias wajah dengan menggunakan pemoles pipi, gincu, bedak yang tebal, sanggul yang halus, kebaya dan jarit untuk membalut tubuh lelakinya, tubuh yang seksi dengan payudara dan pantat dibuat besar serta perubahan nada suara dan gesture keperempuanan.

Perubahan tubuh para tandhak Ludruk Lerok Anyar tidak hanya untuk menunjukkan identitas keperempuanannya namun, juga untuk memberikan kesan sensual kepada penonton laki-laki. Penonton adalah juri yang akan membuktikan tingkat keberhasilan para tandhak untuk menunjukkan keperempuanannya. Penonton laki-laki merasa terpuaskan hasrat sensualnya ketika melihat tubuh para tandhak yang sangat cantik. Melalui tubuh para tandhak penonton laki-laki dapat dengan bebas mengimajinasikan figur perempuan cantik. Perempuan cantik adalah representasi keindahan yang sempurna bagi laki-laki, melalui tubuh para tandhak mereka mendapatkan keindahan tubuh perempuan yang diidamkan. Tubuh tandhak adalah kesempurnaan tubuh perempuan yang terdapat dalam realitas yang salah (transgender).

Tampaknya para tandhak menyadari betul bahwa kesempurnaan itu hanya terdapat dalam imajinasi sehingga, mereka membiarkan para penontonnya untuk terus berada di sana dengan menciptakan batasanbatasan antara realitas dan imajinasi. Oleh karena itu, hubungan antara tandhak dan penonton hanya berada di panggung karena panggung mampu memberikan ruang imajinasi. Sementara, para tandhak menjaga interaksi di luar panggung karena di luar panggung atau realitasnya dia bukanlah perempuan. Saat para tandhak membiarkan atau membuka hubungan penonton dengan tandhak di luar panggung akan 
menghancurkan imajinasi yang sudah terbangun.

\section{Daftar Pustaka}

Achmad, A. K. (2006). Mengenal Teater Tradisional di Indonesia. Jakarta: Dewan Kesenian Jakarta.

Butler, J. (1990). Gender Trouble: Feminism and the Subversion of Identity. London dan New York: Routledge.

Butler, J. (1993). Bodies That Matter: On The Discursive Limits Of "Sex". London dan New York: Routledge.

Freud, S. 2006. Pengantar Umum Psikoanalisis. Yogyakarta: Pustaka Pelajar.

Kasemin, K. (1999). Ludruk sebagai Teater Sosial Kajian Kritis Terhadap Kehidupan, Peran dan Fungsi sebagai Media Komunikasi. Surabaya: Airlangga University Press.

Mosco, V. (2009). The political economy of communication. London: Sage Publication.

Yash. (2003). Transseksual: Sebuah Studi Kasus Perkembangan Transseksual Perempuan Ke Laki-Laki. Semarang: AINI. 